\title{
Religion under the Sign of Crisis
}

At the height of Ambon's war, a small stone surrendered by a Muslim to a Christian on an urban battlefield circulated with stunning effect in a Christian prayer group. Within no time, it infected this core scene of Christian worship and community, triggering illness and possession, turning the group's prayers into a Qur'anic reading session, and inserting the spectral presence of a North Malukan sultan's daughter into its midst. This scene of haunting and radical displacement sums up so much of Ambon's traditional Protestant community's dilemma. At the same time, it gestures, if obliquely, toward the possibility of generosity as opposed to hatred toward one's others, of moving beyond the friend-enemy dyad to include a third term, that of the neighbor. Apart from what Ambon's possession reveals about religiously defined subjects during the conflict, it also attests to the erosion of the carefully policed difference between magic and religion by church and state. In this chapter, I pay special attention to the sites where the defensively upheld distinction between Muslim and Christian broke down and to the capacious waywardness of things as symptoms of a world in the grips of dramatic change. In doing so, I rely on a symptomatology of crisis to track the shape-shifting movements of subjects and objects and the ways in which religion in the city became dramatically refigured.

Following the previous chapter, Ambon's scene of possession may come as a surprise. It may require a leap of imagination to recall that, besides Christians, and in particular Protestants, others also exist in the city. The painted landscapes - the Christian enclave folded in upon itself, the Pancasila Jesus stretching diversity under the sign of the Christian universal, or the masculine street culture congregated around its newfound Jesus icon-equally banish whole parts of urban sociality to the pictures' invisible, if energizing, backdrop. With 
what can only be considerable effort, they elide any hint of a Muslim presence but also of any locations, settings, or situations where Muslim and Christian women, men, and children willingly or unavoidably commingle-whether in the transactions of everyday living, in banal or extreme violence, or in settings of mutual hospitality and joy. If not the paintings, then, the synopsis with which this chapter begins intimates other spaces where Muslims and Christians meet-however problematically - here, around a venomous object that indexes practices that may not be embraced by all but are undoubtedly understood.

\section{Times Rich in Demons}

This chapter is about the terrain that Muslims and Christians inhabit together; it assumes that, living in the same city, they are part of a common world, where they make up Ambon's urban crowds, walk and brush shoulders in its offices, schools, and streets, that they communicate in the same vernacular Ambonese Malay, share numerous habits and traditions and, by and large, even the same food. It is also about the terrain that these Ambonese share with the many migrants who also dwell in the city, the large majority of whom are economic migrants and Muslims from, predominantly, South Sulawesi. By extension, the chapter addresses the diversity among coreligionists themselves that, thus far, I have glossed, for the most part, simply as Muslim and Christian.

Yet, this chapter also explores how this terrain in common is not as straightforward as this brief description makes it seem and how, in this, as with much else in this book, we may take a cue from the city's street pictures. The argument of this chapter is that the project of cohabitation, while deeply fraught in the aftermath of war, is under any circumstance a project rather than a simple empirical given. Or, in other words, that beyond the powerful pragmatics of living together, cohabitation needs to be imagined in particular ways. The Christian pictures foreclose any such imagination. Rather, they reveal how complicated and contested the project of cohabitation can be, especially in the wake of war. Still, to go by their evidence alone would mean missing the myriad ways that cohabitation manifests itself in Ambon City, obscure as well as more obvious. I explore this proposition by homing in on a number of contact zones and conjunctures where Muslims and Christians, in communication and exchange, avoidance and aggression, have shaped their lives together, side by side and jointly, today and in the past, in Ambon City, on the larger island, and on neighboring ones. As an especially radical instance of Muslim and Christian cohabitation, the scene of possession with which this chapter began has the virtue of raising a number of the most salient issues I address here. 
Sometime during the war, a spate of possessions afflicted some among the city's Christian population. A brief account of these happenings, told to me by the GPM minister whose home prayer room I discussed in the previous chapter and who acted as exorcist during the events, will suffice. The account forms part of a longer narrative in which the minister railed against the widespread recourse to magic by Christians and Muslims alike during the war. The possessions began in a Christian prayer group of five persons when the protagonist of the story-a migrant Muslim convert to Christianity and city resident-introduced to the members a small stone that had been given to her by a Muslim woman clad solely in black, a feature that marks this woman as foreign to Ambon. The Javanese Christian convert obtained the stone from the Muslim following a fight between the two within the context of a larger confrontation between Muslim and Christian forces in the city's Ahuru neighborhood. When the Javanese woman prevailed, the Muslim war leader surrendered the stone to her opponent. Once it began to circulate within the Christian prayer group, strange things began to happen. Whoever held the stone fell ill. More unsettling, though, was that whenever the group sat down to pray, they found that they could not, or felt themselves lifted out of place, or prayed as Muslims with their hands held out flat and open in front of them.

The first to be possessed was the Javanese convert at the refugee camp to which she had fled as the latest in a series of similar displacements; the other group members quickly followed suit. Exorcism conducted by two ministers at the GPM's head Maranatha church and backed by the congregation, alternating between prayer and song, disclosed the following: the spirit possessing the Christian convert identified herself as Yanti, the Muslim leader against whom the Javanese had previously stood in battle, but Yanti was merely her Ambonese name and personality. According to the spirit's own declaration, Yanti was none other than Salma, the Muslim daughter of the sultan of the North Malukan city of Ternate.

For many of those in Ambon with whom I spoke in the mid-2ooos, these were "times rich in demons." One way of understanding them, in Michel de Certeau's terms, is as a "diabolical crisis." 2 The import of such crisis, he offers, lies in its disclosure of the fault lines and imbalances permeating a culture, as well as in the way it hastens this same culture's transformation. In situations like that of Ambon during the war, where uncertainty reigned supreme, the taken-for-granted social arrangements and values of everyday existence were shot through with suspicion and hollowed out, and the world shifted intolerably under one's feet, deviltries abound as both symptoms and transitional solutions. ${ }^{3}$ Ambon's possession appears to lay bare the fault lines of a highly fraught, religiously mixed urban society under radical revision. It came via a migrant Muslim 
convert to Christianity, turned a Christian prayer group into a Qur'anic reading session, and introduced into the core of Christian worship the formerly powerful, ancient North Malukan sultanate of Ternate, which, significantly, had become the new capital of an almost wholly Muslim North Maluku province in October 1999. At the story's center is a confrontation and a treacherous object issuing in a poisonous transaction between its two women protagonists, a Muslim war leader, on the one hand, and a multiply displaced Javanese Christian convert, on the other.

One part of this story unfolds into a larger account of this societal revision, comprising, among other things, the changing status and location of religion today, not just in Ambon but more broadly in Indonesia and beyond. ${ }^{4}$ Here, I consider the wide-ranging transformation of religion's terrain in the postwar city via the narrative of cross-religious spirit possession. In the most immediate sense, the public drama of Christian erasure and usurpation of place betrays the anxieties, shared by many of his fellow clergy, of the GPM minister who recounted it: anxieties regarding the waning of the power of Ambon's oldest church and, with it, that of the city's traditional Protestant Christian elite. Relatedly, the minister's account appears to register the fears and dismay of many Christians regarding the split, under Indonesia's new decentralization laws, of the former province of Central Maluku into a truncated, religiously mixed Central province and a new, predominantly Muslim North Maluku one. Intimated as well in the occurrence of possession among members of the minister's congregation, and even more in the exorcism held in Ambon's Calvinist Protestant church, is the insidious Pentecostalization overtaking the GPM from within.

Witness to an unhinged, tumultuous world, the minister's account identifies the threats to church and congregation from without but also, equally disconcertingly, those from within. The profound disturbance at its core, suggested by the cross-religious character of the possession, raises questions about the religious integrity of the subject possessed, the nefarious exchange precipitating the possession, and the contagious force it unleashed, along with the larger uncertainties and turmoil that infuse the story as a whole. These questions include: What does it mean when a Muslim spirit-a force that cannot be ignored-seizes upon and usurps the place of a Christian subject? What kinds of concerns might be at play when such Muslim agency can interrupt the space not only of an individual Christian but of the larger Ambonese Christian community by infiltrating its most intimate sites of worship? How does the status of the event's protagonist-both a migrant outsider and a Muslim convert to Christianity, and thus a multiply split subject from the start-complicate the scene of possession? And what, by the same token, should we make of the doubled spirit of the Muslim war leader who overlays the Ternatan sultan's daughter? 
Why is the societal and religious displacement identified with women and rooted in the material transaction of a moving stone? What might these multiple layerings and porous cohabitations and inhabitations tell us about the disjunctures, interfaces, and entanglements between the city's heterogeneous Muslim and Christian populations, between native Ambonese and migrants, or, indeed, among coreligionists themselves? Lastly, if most urgently, what might this suggest about how the inhabitation of possession might contain or not contain possibilities for a future cohabitation of Ambonese Christians, Muslims, and others in this historically mixed and migrant city?

\section{Conversion's Unstable Alchemy}

If conversion can be understood generally as a narrative through which persons apprehend and describe radical change in the significance of their lives, then the collapse here of conversion and possession into each other proclaims even more dramatically not only the presence of radical change but also the enormous difficulty in grasping or making sense of it. ${ }^{5}$ To be sure, conversion takes many different forms and is often a highly fraught and complex process with, among other things, implications for people's sense of history and the experience of rupture or continuity in ways that depart from this Pauline model of conversion. ${ }^{6}$ When conversion is understood as a singular, momentous act, it may also cause profound confusion and distress, all the more so when this is carried out under duress. ${ }^{7}$ At issue here, however, is less the experience or process of conversion than its rhetoric in the context of Indonesia's, and especially wartime Ambon's, complicated religious plurality. Outside of marriage, where the woman commonly "follows the husband" and adopts his religion, conversion in Indonesia is especially charged since it often goes together with accusations of alleged proselytization on the part of either Christians among Muslims or Muslims among Christians. Not only are the Indonesian terms for proselytization (Kristianisasi and Islamisasi or Christianization and Islamicization) much more loaded than their English equivalents, but they also circulate widely in both secular and religious media, as they did repeatedly and provocatively during Ambon's war. Conversion's representation as a dramatic scene of enlightenment has also been a recurrent theme in several highly popular contemporary Indonesian films. ${ }^{8}$

"Baptismal children of mine," the minister claimed, "who have converted from Islam to Christianity, generally speaking, see an apparition [of the Lord's face]. I always tell them, "When you pray, ask the Lord to see His face so that you will be convinced.' And finally they get it. He comes and blesses them. It's extraordinary." Whenever converts came up in conversation during my 
fieldwork, as they did from time to time, it was with an analogous sense of the miraculous, as if a singular species of being was being invoked. Occasionally, converts were pointed out to me-all Muslim women who had married into Christian families-commonly with a lowered voice, but such persons were few and far between. ${ }^{10}$ Not only were they often spoken of with a certain reverence but, along the lines of the minister's claim, singled out from their coreligionists for signs of divine attention. Of a woman from "the other side," for instance, who ran a bustling lunchroom, it was said that only God's blessings could explain her remarkable business success. By the same token, these examples suggest that converts enjoy special scrutiny-and, presumably, even more during Ambon's religiously inflected war. As in many religious traditions, converts encode a risk, whether this is conceived of as an inherent potential for duplicity, the dangers of "backsliding," or as an ever-present reminder that any claims to universality are always already contested. Since it is women and not men who convert upon marriage, it is women, too, who are most suspect, as the confrontation between the Javanese convert and Muslim war leader suggests. If the former publicizes the perils of backsliding in an especially dramatic form, the latter gifts a poisonous stone that potentially endangers the entire congregation.

But the possessed Javanese convert is less important for any resemblance she bears to the handful of Muslim women in Ambon who became Christians than to the potentially treacherous, unstable alchemy that conversion evokes. Folded into the fraught, affectively charged figure of the Javanese convert, it is possible to discern not only an interreligious interpellation but also the perceived threat of the GPM's eclipse by alternative religions: on the one hand, the Christian's unavoidable haunting by the Muslim, a form of radical cohabitation, to which I will return, on the other, a matter of great urgency and, arguably, one of more immediate concern for the GPM than the Muslims after the war. This matter is that of the numbers of GPM Christians, augmented during the conflict, who abandoned their church for what they deemed more promising alternatives, in a wave of "conversions" away from the GPM. Put otherwise, the figure of the Javanese convert doubly incarnates the threat of displacement for the Ambonese Christian subject-conjuring, at one and the same time, a usurpation of place by one's others and an abandonment by those akin to oneself in favor of more compelling options. Both the Javanese and black-clad Muslim war leader are not only marked as other but as foreign - the first being a migrant and the second, visually, akin to the jihadi women who, at the time, were only recently seen in Ambon.

Beyond conversion, I home in on the treacherous instabilities afflicting both subjects and objects in the minister's account and, more generally, of appearances 
in a world in devilish disarray. In ordinary times, the manner in which other people appear to you and the knowledge you have of them remains largely underscrutinized. Similarly, the things that make up one's daily environment, including the cast-off refuse of city life, figure for the most part as unexamined fixtures of everyday existence. ${ }^{11}$ In the decade or so under consideration in this book, difficult years marked by conflict and the myriad efforts to move beyond it, the ways in which persons and things manifested themselves, and especially the trust in such manifestations, often faltered. Not only might their familiarity be deceptive, triggering the aesthetics of depth I discussed in Chapter 1, but any sense of certainty tended to dissolve, as I show below. The implications of such alterations in subjects and objects are potentially much more than phenomenological. In such circumstances, the prevailing semiotic ideology or historically grounded background assumptions that constitute and organize people's experience of the materiality of semiotic form may come into question such that this materiality itself may become a significant provocateur of historical change. ${ }^{12}$ While it would be a stretch to describe the stone at the heart of the minister's story as an agent provocateur of such magnitude, it is still possible to see it as an augur of some of the momentous transformations that took place in Ambon at the time-in urban religion, generally, but here specifically from the vantage of the GPM, as told, admittedly, by one of its more maverick ministers.

In what follows, I deploy a symptomatology of crisis, attending to the shapeshifting, death-wielding movements of persons and things and the discourses that surround them as an entry into urban religion's reconfiguration and the diffuse transformation of appearances, both being among the most significant changes wrought by Ambon's war. This symptomology operates by taking the signs and material disturbances of a violent situation-including outward appearances that seem at odds with and peripheral to the more serious business of war and were, indeed, often experienced as anachronistic or heterotopic-as core symptoms that betray just how much violence and destruction came to suffuse and rework from within the everyday experience and lifeworld of ordinary citizens.

\section{Religion under the Sign of Crisis}

Let me begin by looking more closely at the rolling stone that first shifted hands on an urban battlefield, setting this story in motion and contaminating Christianity from within, triggering possession among congregation members, and substituting Christian with Muslim practice. A token of the treacherous magic that, following the minister, untold numbers of Muslims and Christians would 
have relied on in the violence and that, beyond it, would exercise a diffuse influence in everyday Ambonese life, the story of the stone served as an example of the dedicated spiritual warfare conducted behind the conflict's battlelines. In his pastoral work with "broken families," acts of aggression, overwhelmingly sexual in nature, alcohol abuse, and gambling could often be traced back to potent baths given to baby boys, he told me, or to talismanic cords tied around infants' waists, meant to instill them, early on, with the requisite qualities of male prowess and hypermasculinity. ${ }^{13}$ Indeed, he attributed the tenacious ferocity of Ambon's conflict to the widespread deployment of what he occasionally called, in English, "magic" or "occultism" on both sides. Symptomatic of a much larger problem - the sway of pagan, tribal religion over the local population-this would have manifested itself in the recourse to magic on both sides during the violence-whether to protectively "seal" their villages against enemy assaults, summon fierce Malukan war captains of bygone times to their side, or otherwise activate the martial prowess for which Malukans are renowned in Indonesia.

Relating how members of his congregation betrayed their engagement with such hidden forces, the minister detailed how, during the multiple wartime prayer sessions convened at the Maranatha church, they surrendered en masse the talismanic cords and amulets that they tucked within their clothing:

During the violence, I held a service every afternoon at 3:00, there at the Maranatha. It went on like that for four years, every afternoon.

From the year 1999 until 2003 when things were somewhat quiet. We did this every afternoon without fail and during the first four months alone we collected four large boxes of cloth cords [A.M. tali kain]. We did this during the service, and they voluntarily surrendered them-four boxes of cloth cords. Actually, I had a prayer team, there was a prayer team. So we always prayed and asked people to do this voluntarily after they had received the prayers and words of the sacrament. After that they would come, "Sir, I would like to surrender this, please pray over it so it can be removed." There were people who wore them to avoid the violence and put a distance between it and themselves, while others [engaged in the fighting] felt, "If I wear this, then later I will be killed [on the battlefield], so it would be better if I turned it in." Yes, it was like that. "It would be better if I depended on God." So it was really extraordinary, ma’am. For four years, we held those afternoon services. It had quite an impact on changing things for the better. Young people who liked narcotics or alcohol would come and surrender themselves. Women with shattered family lives, like one 
who came devotedly for an entire year and then came to inform me, "Sir, my husband has come home. Because of the minister's and my own ceaseless praying." She came every afternoon. ${ }^{14}$

Magic across Indonesia's extensive territory is remarkably diverse, rooted primarily in local practice, and shaped, among other things, by its interaction with official religion and statist discourse on modernity and by the relatively urbanized or rural character of the setting in which it occurs. At the same time, the wide currency of familiar terms deriving from different localities, the interregional Malukan trade in protective amulets and medicines involving migrants from beyond the province, and the GPM minister's invocation of the English terms magic and occultism suggests how widespread the relatively underground traffic in magic is in a country that officially bans the sale of magical spells and artifacts. ${ }^{15}$ If the minister's use of English underscores magic's mass mediation and, more specifically, the popularity in post-Suharto Indonesia of supernatural horror films and television serials and of books like Dan Brown's Da Vinci Code, which circulated among educated Christians and which he claimed to have read, North Maluku's magic trade and terminology evince a similar if, generally, older cosmopolitanism. ${ }^{16}$ "People are as likely to refer to sorcery by the Javanese term santet, by the general Indonesian terms guna-guna or ilmu hitam, or by the English term black magic as they are to use local terms as doti, bodiga, or fiu-fiu." Trade in the objects of magical protection in North but also Central Maluku comprises "spells (syarat), amulets (ajimat), or magical objects such as magically empowered semi-precious stones (batu dalima), herbal roots, miniature versions of the Qur'an, or antique Javanese knives (kris)" and is carried out "by a steady flow of predominantly Javanese and Buginese healers [who] arrive in ... Maluku to sell their protective medicines." ${ }^{17}$ In Indonesia generally, forms of magical protection are known to be rampant among the Indonesian police and military-with bracelets made of jet black coral especially popular-as well as prevalent in politics, from the lowest to the highest levels. ${ }^{18}$

In Ambon, the minister reminded me, men and boys would often be ritually bathed before heading into battle, a practice intended to instill invulnerability to bullets and other weapons that recalls the potent baths given early in life to Malukan boys. ${ }^{19}$ A journalist from a North Malukan newspaper recalled in 2008 how he had stood among a crowd of men waiting to be doused with water and struck on the back with a machete to achieve this effect, ${ }^{20}$ while a former Muslim child soldier from Ambon told a Dutch Malukan documentary filmmaker how they would pray and be bathed by an older male relative to purify themselves and to foster invulnerability before battle. ${ }^{21}$ The young man also 
mentioned red cloth cords that served as protective amulets, were incanted over by a specialist in local custom, and had to be worn invisibly under clothing "since otherwise others might take you for a Christian since they also use red cloth." 22 The powers and agencies of these and other objects like magical stones circulated profusely in discourse-rumors, ordinary conversation, and apocryphal accounts like that of the GPM minister-that attested to and elaborated upon their doings and effects, thereby not only substantiating "the ubiquity of supernatural belief as interpretive practice in contemporary Indonesia" but also consolidating the "narrative experience" particular to Ambon's war. ${ }^{23}$

Not surprisingly, such powers are controversial and suspect. If former Muslim soldiers were wary of speaking of "black magic," calling the topic sensitive, a Christian described how he had fought alongside a man who appeared invulnerable to bullets and machete attacks until he lost his cloth cord. "Then he was hit by a bullet. This is how we knew that Christians also used these things." ${ }^{24}$ What strikes one in the brief enumeration of objects affording supernatural protection is how-notwithstanding the careful hedging of religion, whether Christian or Muslim, against magic-a miniature Qur'an (or, for that matter, bible or Catholic prayer book) could operate comfortably alongside an amulet or potent stone. Similarly, men, boys, and occasionally women who set off to battle might magically fortify themselves but also pray beforehand with their coreligionists in a church or mosque. Notwithstanding such accommodations, the resurgence in a reliance on sources of magical protection "signaled a departure from religious and modernist standpoints that were abandoned as young men turned to the magic of their village elders before heading into battle." ${ }^{25}$ For city dwellers in particular, especially Christians, the uncanniness that always accompanies the supernatural's appearance would have been enhanced, given its overall banishment to the edge of urban existence for a long time. Sorcery in the city is also uncanny since it turns the everyday materiality of village life, things like sago pith and thorns, into lethal weapons. ${ }^{26}$

\section{Simplifications}

To return to the minister's account, beyond pagan magic's destructive inroads into the GPM congregation, it is the fact of interreligious contagion that absorbs him most. Anxieties about church members whose allegiance is in crisis and identity uncertain, who may be swayed by alternative sources of power or drawn to a rival religion animate the tape from our conversation. It is worth recalling that the minister who related Ambon's wartime plague of possessions is the same who cordoned off a prayer room in his home. At work, much as at home, his ideal horizon is seamlessly Christian, his primary concern pastoral, and his 
overriding objective that of securing religious identity uncompromised in its proper place. Yet however one looks at it, the Javanese protagonist of the minister's account who sets the calamitous stone rolling augurs anything but that. Rather, she is a figure of religion shot through with competing forces and dangerously on the move in a city where Christians and, especially, GPM members were highly cognizant of how much less powerful and prominent they now were, while many also foresaw their genocide at Muslim hands. Inherently duplicitous, she spectacularly discloses the inability of the GPM to control or even gauge the shape of the Christian self, a self that, in so many ways, appears compromised from the start.

For a host of reasons, not the least because of the way it foregrounds his heroic engagement with the demonic forces assailing Ambon, the minister's account should be understood as highly mythologized. Nonetheless, the reference to Ahuru as the location of the standoff between the Muslim and Christian women and the site of transfer of the infected stone places these events temporally around June 2000, when a large confrontation and mass exodus of Christians-including Catholics-took place in that neighborhood. This was also the time when jihadis from Java began to make their presence felt in Ambon, having begun to arrive in the city the previous month, so that fears among Christians could be expected to have intensified exponentially. It is also a key factor that helped to draw the Catholics into the conflict, since the jihadis targeted Christians indiscriminately, making no distinction between Protestants and Catholics. Their presence was highly visible-male members of the theatrical, media-sensitive Laskar Jihad could be easily recognized due to their white robes and untrimmed beards. ${ }^{27}$ When women joined them-often Ambonese Muslim women who "converted" to the group's strict neo-Salafi lifestyle-they commonly covered themselves in black, looking much as one imagines the female war leader in the minister's account. ${ }^{28}$ Besides mention of the Maranatha church and Ternatan sultanate, the inclusion of the telltale Ahuru, with all that this place name could be expected to evoke among both Protestants and Catholics, makes more palpable even the sense of violent usurpation motivating the minister's account. ${ }^{29}$ A figure of terrifying disturbance at the center of a scene of erasure, the Javanese convert's seizure subsumes a number of displacements that summarize the Malukan conflict as a whole.

First and foremost among these is the displacement of anxieties about the "incompleteness" of religious identities, boundaries, and hierarchies prefiguring the outbreak of violence, while the forced displacement of neighborhoods and villages by armed groups across the religious divide promoted the spread, transformation, and, finally, de-escalation of the violence..$^{30}$ Indeed, as internally displaced people, or IDPs, fled violence, their arrival to would-be sites of refuge 
often portended and could precipitate violence in these places, creating a deadly contagion effect. Gradually, however, "the violent eviction of people from neighborhoods and villages also effected the spatial segregation and simplification of Christian-Muslim communities seen in other sites divided by interreligious violence elsewhere around the world, producing an interlocking binary spatial grid and inside/outside polarities,' with the 'proliferation of interfaces, the barricading, and the influx of refugee populations' reorganizing towns and villages into a highly militarized and religiously coded topography." ${ }^{31}$

Resistance to displacement occasionally took place, but then only by giving in to conversion. In the face of impending displacement, some Muslim families who lived in neighborhoods where they represented a minority, like Ambon's Batu Gajah, opted to convert to Christianity rather than relinquish their homes and horticultural plots to Christians. ${ }^{32}$ Much more common on both sides were circumstances where people were simply driven out or compelled by the violence to abandon their neighborhoods, leaving their property and possessions behind. Several Christians told me that after the war, Muslims would sell their homes cheaply to Christians in areas that had become religiously homogenized, an outcome of the conflict they deemed favorable or "nice," in the sense of economically advantageous. ${ }^{33}$ Presumably the same circumstance the other way around resulted in the same solution. Given that Ambon's cadastre burned down in 2004 and the understandable -in these circumstances-pragmatism of city officials in resolving property and land disputes, much remains and presumably will remain unsettled for many years to come, if not, indeed, forever. Apart from the violence that accompanied it, the "simplification" of large parts of Ambon into religiously defined enclaves often had disconcerting and jarring results. In a city emerging from a conflict waged in religion's name, "houses of worship in the wrong place," such as mosques arising in what today are Christian neighborhoods or churches abandoned in what have become Muslim ones, are now traces of a recent, wrenching past. ${ }^{34}$

Overlooking the city's rearranged, religiously coded topography in the immediate postwar years, Ambon's street paintings may be seen simultaneously as signposts and effects of simplification. To understand why this is so, we need to return, briefly, to the years immediately before the conflict. At this time, an anthropologist working in one of Ambon's most cramped, impoverished, and largely illegally settled neighborhoods registered an excess of protective amulets tacked above the doorways of migrant homes. ${ }^{35}$ The proliferation of such overt signs of animosity and suspicion were an expression, as he saw it, of the "dangers of living so close by those who were 'strangers' in significant cultural and social terms." ${ }^{36}$ In retrospect, this would have fed the mob response and vengeful strikes on Christian Ambonese neighbors "who had demonstrated their sense 
of privilege and superiority in various ways over an extended period." ${ }^{37}$ Important, too, was the sense of alien but proximate space, something that was felt on both sides of the conflict. ${ }^{38}$ Unfortunately, the fears of the many migrants who clearly did not take their presence in Ambon for granted were borne out during the first days of the war when migrants from South Sulawesi-Buginese, Butonese, and Makassarese peoples, or the derogatively collectivized BBMersbecame the target of mass aggression and fled the city in droves. ${ }^{39}$

It would not be a stretch to see the Jesus billboards and murals standing guard at Christian neighborhood entrances, along similar lines, as huge amulets aimed at Muslims and other potentially hostile strangers. Much like an amulet, the material presence of God's image served the community as a shield. In soliciting God's presence and bringing him into vision here in Ambon, the street pictures seemed to fulfill a protective function analogous to that of the dried seahorses and medicinal phials adorning the lintels of Butonese homes, or those migrants especially reviled by both Christian and Muslim Ambonese. ${ }^{40}$ Beyond mere analogy, the paintings can be seen as successors of a sort to the magically potent phials and seahorses. Insofar as the violence succeeded in religiously and ethnically purifying a large majority of Ambon's neighborhoods, blocking the city into homogeneous swaths of red or white territory, it would make sense that the signs erected against threats from hostile neighbors within-dried seahorses and the like-would shift to the neighborhood's external boundaries to face the threats now directed (in principle) exclusively from without. So, too, does the substitution of Jesus's gigantic face for the tiny, if public, tokens of a more traditional power accord to the logic of a conflict that came to be carried out, already early on, in religion's name. Such religious or magical gating in the physical space of the city exemplifies the material ring fencing that often prevails in a field of competing religious discourses. ${ }^{41}$

Still, more than any of the above, it is the Javanese Christian convert's serial displacements that best summarize - and complicate-the process of "simplification" fought out in Ambon's streets. From this perspective, poetic justice may explain why when, following successive flights, the convert finally arrives to a place, this place is a refugee camp. Not only is this setting emblematic of one of the war's most devastating forms of social dislocation, that of the IDP, but as such it offers a fitting mise-en-scène for another aspect of the Christian subject's radical dislocation-it is in the refugee camp, after all, where the serial possession of GPM congregationalists takes place. ${ }^{42}$ Yet the particular form taken by the displacements in the minister's story also confounds this process by hinting at how simplification generates not only stark separation along religious lines but also porosity, admitting points of passage between Muslim and Christian and making it less absolute than it may seem. In what follows, I consider 
points of passage between Christians and Muslims and among coreligionists, along with the efforts to control them.

\section{Terms of Coexistence}

"Coexistence," following Benjamin Kaplan, a historian of the religiously mixed societies of early modern Europe, "exposed members of each group to rival beliefs and practices, and with that exposure came temptations, pressures, knowledge of alternatives and the possibility of choice. ... Life in a mixed society presented rival groups with both opportunities and perils-the opportunity of gaining members, the peril of losing them." ${ }^{43}$ Already before the war, the GPM had begun to feel the competitive pressure of other, primarily charismatic, churches that are relatively recent in Maluku. Many of these, like the popular Pentecostal churches, appeal especially to Ambon's many young people ${ }^{44}$ who are drawn by their lively prayer sessions, musically and technologically supported religious services, their outreach programs, and to a not negligible extent, their cosmopolitan allure-in short, by their general ambiance of conviviality, fun, and modernity. By comparison, the GPM had begun to feel stiff, formalistic, and out of touch with young peoples' lives. The possibility of choice, present in principle in any situation of religious plurality, became an urgent one during Ambon's war when the sureties of everyday existence seemed to evaporate and the need for security, protection, and community became enhanced, forcing people to confront and evaluate their alternatives. Choice can only be understood within this context and is not, in other words, assimilable to an individualist consumerist position - the kind often identified with conversion - or to that of an individual consciously, willfully, and "freely" articulating her choice. ${ }^{45}$ Stories of conversion from Ambon suggest a much more complex reality-commonly, a process of gradually coming to conversion, even if it is storied afterward as a singular momentous change. There were also some group conversions of families or, more spectacularly, the conversion to a stricter neo-Salafi form of Islam that was entailed in the mass wedding ceremonies in which local women married jihadi soldiers during the war.

Unlike many of the converts I met in Ambon who had left the GPM for another denomination due to a personal experience with violence or a general disillusionment with the role of the city's traditional church during the conflict, a young woman who I will call Feby had been drawn to Pentecostalism before the war. In this respect, she was part of a slow trend that was already underway when I first visited Ambon in 1984. Having taught herself some English, repeatedly befriending and offering her services as a guide and translator to the foreigner researchers and visitors who came to the city, Feby seemed especially 
taken with the cosmopolitanism that characterized her church. Whether a coincidence or not, the English acronym ROCK of the Representatives of Christ's Kingdom church, with its evocation of not only foundational solidity but also Western popular culture, does seem designed to appeal to Western-oriented youth. Besides its name, the church's international orientation comprises regular visits from foreign preachers, singing in English, images of traffic-swollen urban highways or San Francisco's Golden Gate Bridge projected onto huge screens during select religious services, and a sizeable contingent of foreignmarked Chinese Indonesians among its members. ${ }^{46}$ As one loyal GPM member put it when speaking derogatively to me about Ambon's Pentecostal churches, "They are full of big people, moneyed people, with lots of Chinese." She went on to complain specifically about ROCK, alleging that it paid people to become members, that they offered a lavish service, then summed up her grievances by claiming that the GPM disapproved of these churches because there were "outside of the GPM."47 If nothing else, her blunt remarks demonstrate how much, beyond any denominational differences, the mere fact of competition was a problem for the old Protestant church.

In addition to her church's cosmopolitanism, what also appealed to Feby was the less hierarchical, more intimate relation this institution envisioned with God as compared to the GPM. In one of our conversations about religion, Feby spoke not only of how the GPM was changing due to competition from the Pentecostals but of the difference between the old church and ROCK. ${ }^{48}$ Striking a rigid military pose with her arms pressed firmly to her sides, Feby evoked the stiff, immobile attitude of the GPM as she related how even these Protestants had begun to depart from their characteristically formal liturgy by introducing "praise and worship" services. To underscore the contrast between the two denominations, she noted how God in the Bible is addressed both as "my father" and "my friend" and that, although both describe an intimate, familiar relationship, she preferred the latter. Reminiscent of the desire for proximity and presence that underwrites the street pictures, Feby insisted that God not be treated like something distant and intangible or, as she put it graphically, "like a ghost." As I proposed in the last chapter, one of the changes occasioned by the war was that the Christian Ambonese subject began to imagine herself emplaced within a larger visual field. What Feby's comments reveal is how, at the other end of what we might conceptualize as a larger process of refocalization, God undergoes a crucial change in which not only his presence but his tangible presence and humanity is increasingly -in the case of the street art, quite literally - drawn to the fore and made visible. ${ }^{49}$ Refocalization reveals that what is at stake here is more than a perspective or particular way of seeing but an ideologically inflected vantage that permits, in this case, the Christian God 
to come into vision and to cohere as a privileged object of attention. ${ }^{50}$ Refocalizations such as these take place especially in transitional historical moments where what was previously seen one way may take on a radically different appearance, stand in a different relation to its general cultural surround, or disappear from view altogether. ${ }^{51}$

Feby described how she and her fellow church members rejected war fought with "blood and body" as they also distanced themselves from the pictures set up in the streets by GPM Protestants. ${ }^{52}$ She spoke of how she and others erected a "Prayer Tower" when they deemed the situation in the city especially "hot." 53 And how the nonstop, serial praying went on without interruption twenty-four hours a day in which so-called "intercessors" relieved each other at periodic intervals in what was understood as spiritual warfare targeting the devil. Another aspect of this battle of cosmic proportions was a thoroughgoing "healing of the land" carried out both on land and at sea. Teams of about five or six people descended before daybreak upon appointed sites in the city where violence had occurred and that figured on maps that had been drawn up by the church on the basis of research. Admittedly, as a hub of the international spice trade from the early seventeenth century, Ambon's history has been unusually violent and bloody. According to the Pentecostals, blood spilled violently demands a response, but only Christ's blood can eradicate violence's traces from contaminated, blood-soaked land. Feby described how she and her small "team"-a term that, incidentally, betrays the long reach of state bureaucracy into daily life-would set out before dawn armed with Jesus's authority to pour "the blood of Christ," or consecrated wine, on sites polluted by the spirits of murder, adultery, and prostitution. During lulls in the violence, ROCK's teams ventured out while the rest of the city slept to drench the doorways of gambling dens, karaoke bars, and other infected loci with Christ's purifying blood. When I asked Feby why the Pentecostals took such precautions to remain unseen, she mimicked the voice of a fellow urbanite reacting in colloquial Ambonese Malay to encountering her team going about its purifying work: "Hey, are they crazy or what?" Aside from being a comment that exposes the perception of the close proximity of religious others in Ambon's urban environment, this anticipated reaction reveals how much Pentecostals tended to see themselves on the defensive against not only or so much Muslims or Catholics but especially Protestants of other denominations, notably the GPM.

Another young woman, whom I met through her work with a local interfaith group, related how in 2001 her family had left the GPM to join a Pentecostal church. Previously, Rona had been active in a GPM youth group but also occasionally accompanied friends who belonged to one of the city's Pentecostal churches to attend services there. These churches made her feel different-a 
feeling, as she described it, that touched her profoundly-adding in English, "There is more immersion in God." ${ }^{44}$ Her parents, however, were adamantly opposed to the charismatic churches, until a nephew died whose family happened to be Pentecostal and her father was quite moved or "struck" by the service. Both Rona's and her father's acquaintance with Ambon's Pentecostal churches highlight the crucial influence of family and friends in introducing religious alternatives and raising the possibility of choice for others. Since, as recalled by Rona, her father did not want to divide his family between different denominations, family members agreed collectively to convert to the new church and were baptized on the beach in 2001, a good two years into the war. Quite consciously, the family chose not to join one of the city's larger Pentecostal churches but opted for a smaller one that Rona described enthusiastically for the sense of community, small-scale intimacy, and freedom of emotional expression it allowed. Besides the less "general" or abstract language of its services, what she repeatedly emphasized was that "there is no feeling of embarrassment if you want to cry and this provides relief-even my father cries if there is something going on at the office." 55 Throughout Rona's account of her family's conversion, any mention of the war going on at the time was significant for its absence. Yet the characteristics singled out by Rona as exemplary of her church establish an implicit contrast with the GPM. They are also those that came to be valorized during the war-namely, community, intimacy, and emotional expression.

While not always articulated, the sense of how much the GPM had fallen short comes across in the stories of those Ambonese who, in retrospect at least, made clean breaks with the church by converting and radically reforming their lives. In these instances, they described the desperate circumstances that had driven them to convert. By focusing on these different conversion stories, I have aimed to situate the competition that in part describes the relations among the city's Protestants and, in particular, the challenge that Ambon's charismatic churches pose for the GPM. While competition, including invidious comparison, may be a common feature of religiously mixed settings, the intensity of the rivalry, the way it is dealt with by religious leaders and managed by state authorities, the relative porosity or firmness of religious boundaries, and the fluidity or strain in mutual relations all contribute to the great variety of interas well as intrareligious relations across place and time. Along with significant developments at the national level and the impact of globalizing trends and forces - not the least the rise of Pentecostalism - the war in Ambon had dramatic effects on the place of religion in the city, on its everyday practice and manner of integration into social life, and on its public presence. Besides the delineation of stark religious boundaries or "simplification" - stiff versus more 
relaxed liturgical practice, religious services characterized by restrained or more open expression, Christ up close as a friend or distant as a paternal authority-transformation and fluidity also describe and helped to reconfigure Ambon's complicated religious terrain.

Although never static, religious difference within these charged circumstances was exceptionally dynamic, being negotiated again and again on war's unfolding terrain. War, more generally, is a context not always best described as simply one of taking sides. ${ }^{56}$ It can help to promote cosmopolitan identities by bringing together people of different ethnicities and religions (often against their coreligionists) and engendering new patterns of circulation. ${ }^{57}$ Along these lines and notwithstanding the fears of a traditional Protestantism under storm, a pragmatic if tentative ecumenicalism also began to take root in the city during the conflict. Such rapprochement, encouraged by an acute awareness of commonality forged under fire in a "Christian" versus "Muslim" war, involved a détente not only between different Protestant denominations but also between them and the Catholics, marking a revolution in relations among different Christians in Maluku. It also glossed over the fears of Ambon's traditional Protestants regarding the serious competition posed by the newer charismatic churches.

For much of Malukan history, both under the Dutch and thereafter, relations between Muslims and Christians were unequal. Less acknowledged is the fact that relations between Protestants and Catholics were especially marked by rivalry and mutual suspicion. Undoubtedly, there was some mimicry of the Dutch colonizers in this. But at stake, too, were the considerable numbers of as yet unconverted peoples to be fought over in large parts of Central Maluku like Seram and Buru and in the Southeast Malukan islands. To manage this competition, the Dutch maintained the historical dominance of Protestants in Central Maluku, while allowing Catholics to missionize only in Southeast Maluku beginning in the late nineteenth century. ${ }^{58}$ Historically, in some respects then, the Christians had always kept more of an eye on each other than on the Muslims, something that seems exemplified by the spatial location of Ambon's main religious institutions. Today, as in the past, the central artery of Pattimura Avenue, which began to regain its prewar elegance a decade or so after the official peace, boasts at one end the new and older Catholic cathedral and bishopric offices and, at the other, the GPM's head Maranatha church and synod headquarters. As elsewhere in Indonesia, the city's main mosques, the historic Jamu Masjid and the Al Fatah, are located in the area along the coast or the traditional place of Muslim settlement around the archipelago, while Ambon's newer churches are scattered throughout the city in its predominantly Christian areas (Figure 32). This long-standing settlement pattern explains 


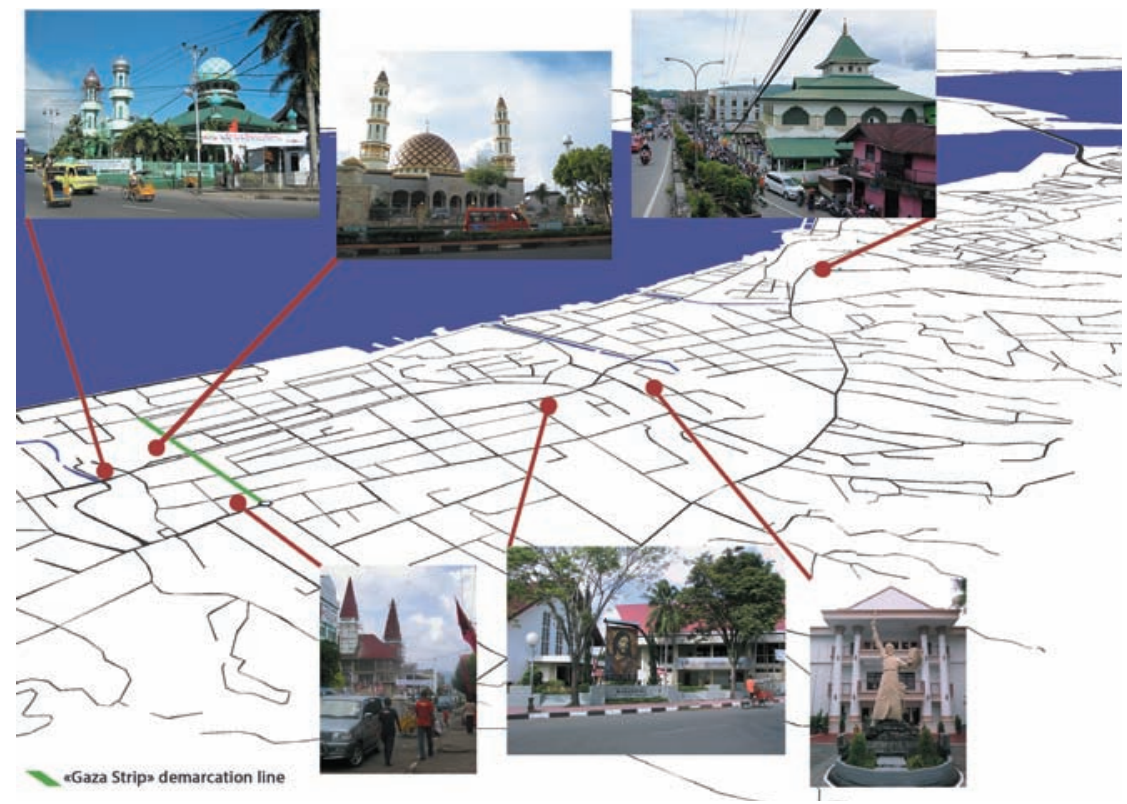

Figure 32. Map of Ambon indicating the location of important mosques and churches and the city's main "Gaza Strip" on A.M. Sangaji Street. From top left to bottom right: Jami Mosque, Al-Fatah Great Mosque, An-Nur Great Mosque of Batu Merah, Silo Church under repair in 2003, Maranatha church, statue of Saint Francis Xavier in front of the Roman Catholic Diocese of Ambon. Map by Marie de Lutz. Photo of the An-Nur Great Mosque of Batu Merah by Ratih Prebatasari, Ambon, 2020. All other photos by the author, Ambon, 2003 and 2016.

why, in Ambon, the Christians are commonly designated as "those who live landside" or "those who live up above [in the hills]" versus the Muslims who "live seaside." 59

Against the historical background of rivalry between Protestants and Catholics and the more recent interdenominational competition among the former, the unprecedented sense of Christian fraternity, the idea that "we are all Christians," is evidenced, for instance, in the inclusive statement of a GPM church council member who commended the Christian street pictures for showing that "Jesus is ... here [and] he gives strength to all Christians-not just Protestants, but also Catholics, Adventists, Pentecostals, Assembly of God,"60 in the practice of "pulpit exchange," following which a Protestant minister would lead a service in a Catholic church and vice versa, and most strikingly in the image of Christ clasping the sacred heart to his chest in some of the city's new Protestant-produced pictures. Also important was the public display of Christian solidarity and show of numbers. In a spectacular demonstration of unity, 
denominations of Protestants joined Catholics in Ambon's streets, totaling about five hundred church leaders in all, in a December 23, 2000, protest against the forced conversion to Islam of Christians at the hands of jihadis in the Southeast Malukan islands of Kesui and Teor. ${ }^{61}$ Once the war was over, Protestants marched behind the Catholics in the latter's Easter Passion parade and the GPM appointed a church representative whose task it was to promote ecumenical relations. ${ }^{62}$ This novel fraternity was not without friction. While lamenting, with obvious amusement, how difficult it is to "organize priests," one Malukan priest recalled the displeasure of the Protestants when a group of Catholic clergymen showed up in their lay clothes for one such joint procession to march alongside Protestant ministers and council members fully arrayed in black. ${ }^{63}$

By 2011, a new portrait of Jesus surfaced on city walls depicting Jesus as a King or Jesus of the Second Coming at a time when most other Christian pictures had faded into the texture of city walls (Figure 33). Personally, for the painter Jhon, these portraits confirmed his stabilized identification with the Pentecostal church ROCK. Emergent at this time, almost a decade after the city's official peace, this mural publicly and graphically confirmed the intense religious mobility of Ambon's Protestants, especially the move of sizeable numbers of GPMers away from the city's oldest church. But the image may also be seen as yet another form of simplification, gesturing toward the GPM's quiet transformation from within. This process comprised deliberate innovations, like a praise and worship service, but also the exorcisms organized by a handful of GPM ministers to liberate afflicted congregationalists-due to their reliance on magical agency, sorcery attacks from envious neighbors, or the mere presence of a bloodthirsty ancestor in their family background. To be sure, the GPM's Pentecostalization is slow, contested, and its outcome uncertain. As one of the GPM ministers at the forefront of this movement told me, exorcisms, not being traditional to Ambon's Calvinist church, remain vigorously opposed by a majority of GPM ministers. In his view, they are not sufficiently aware of just how widespread the dark forces besetting Christians are or, indeed, how best to combat them. ${ }^{64}$

\section{Symptomatology: Treacherous Things}

Objects, object worlds, and the natural and the built environment are implicated in violence-unmoored, displaced, revalued, disfigured, destroyed, or redrawn by its traces, signs, or denial. They help to delineate the lines of battle and act as crucial media of communication and conveyers of friendship or hostility. They have tangible, at times even disastrous, effects, like the tiny stone 

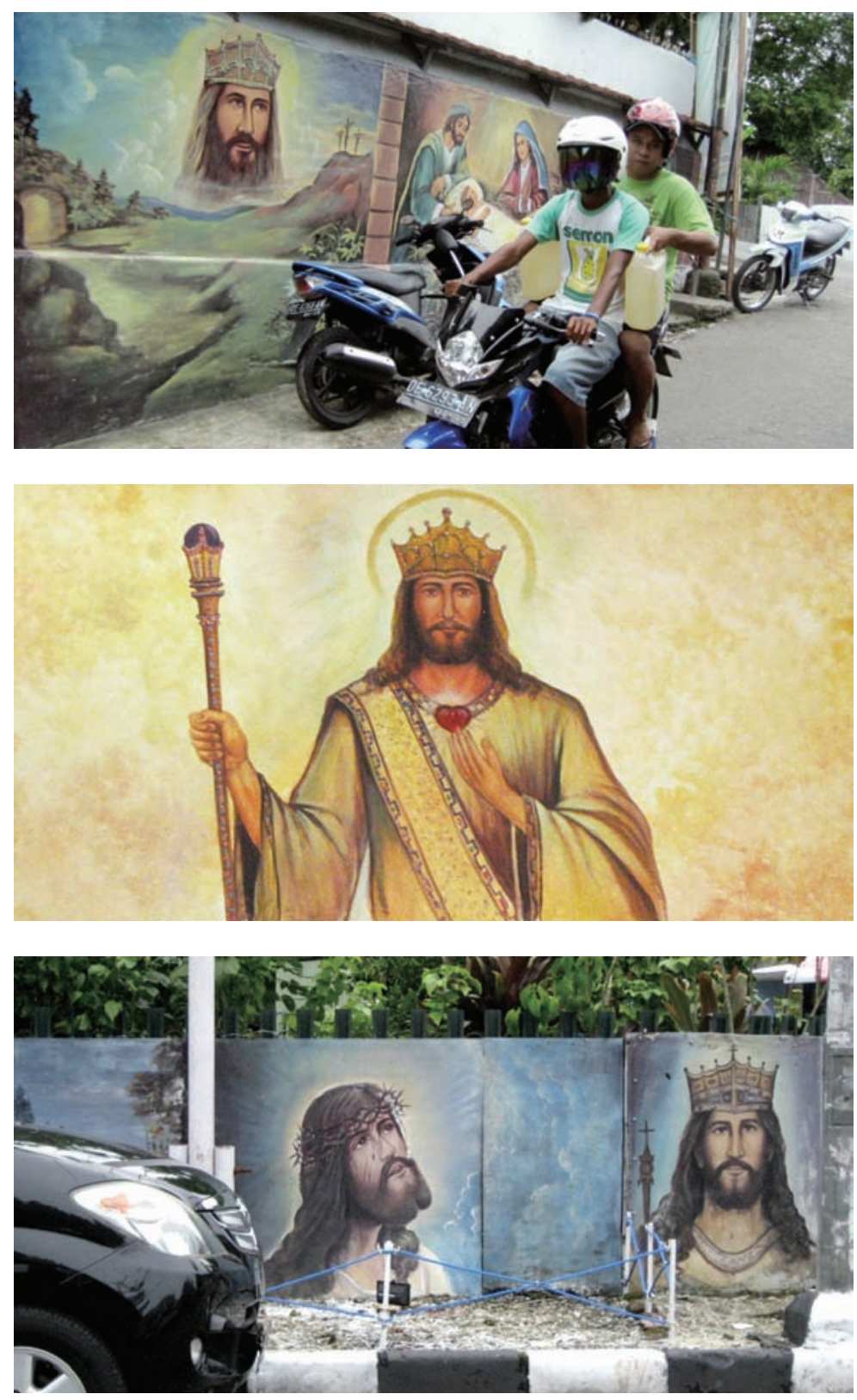

Figure 33. Images of Christ of the Second Coming on two painted murals and, between these, a third painting of Christ of the Second Coming on the interior wall of a church, Ambon, 2005. Photos by the author. 
transacted between a Muslim and a Christian woman, or they may stand in for commensurability or its rupture. Some authors propose that material objects assume special salience in situations of religious plurality, as in this quotation that resonates uncannily with Ambon during the war: "Whether Muslims and Christians are protecting or building one another's sacred places or burning them, or sharing a meal or handshake or refusing to do so, it is in material things that the plural is realized." ${ }^{\prime 5}$ Approaching things as symptoms, this section explores some of the ways in which objects were revamped in style, scale, and import, technologically reproduced, and deployed differently, as well as attacked and destroyed-in short, put to work in war in various ways. I pay special attention to how objects were marshaled and mobilized within the augmented, quickened traffic that both trespassed and redrew religious boundaries articulating anew Christian red versus Muslim white opponents and realigning relations among coreligionists.

If, following the minister, Muslims and Christians resembled each other in their wartime reliance on magic, it was the Protestants who initially turned to the Catholics for protection of a more conventional religious kind. At the outset of the conflict, when Catholics had not yet been implicated in the fighting and the city's bishop profiled himself as a mediator between the warring parties, ${ }^{66}$ Protestants visited priests, requesting rosaries to help them "pass" as Catholics. As the war went on and Catholics were drawn into the conflict, the nature of such requests changed. Over time, things produced by the Catholics and initially sought as aids in the dissimulation of religious identity became increasingly coveted for their ascribed protective powers. To meet this demand, several nuns set up a small industry in Ambon that relied on the easy availability of the photocopy machines whose ubiquity attests to the Indonesian state's enormous bureaucracy and the incessant demands it makes on its citizenry. The nuns turned out photocopied, stapled, pocket-size prayer booklets in large numbers, which were worn on the body as protective devices in battle. Muslims, for their part, carried pocket-size Qur'ans and tiny flasks of holy water to be sprinkled over them should they succumb in the fighting.

Recourse to the readily available infrastructure of technological reproducibility, coupled with the need for protective props, also underwrites the account of a Chinese Indonesian refugee from North Maluku, who spoke to me of the extensive use her future assailants had made of the photocopy machine in her Tobelo store. ${ }^{67}$ Only later had she realized the significance of the multiple sheets that several Muslims commissioned only a day or so before the onslaught upon her town began. Only later, too, did she recognize the crossed swords supporting an open book as the insignia of the Laskar Jihad movement that 
the jihadis who drove her from her home wore folded in neat little packets within their robes. ${ }^{68}$

The protective qualities of such things were often celebrated in stories that circulated on both sides during the war. Take, for instance, this account of a young refugee who spoke of how, upon fleeing an attack by Muslims, she left her father with a "pocket bible, to protect him" as he remained behind to guard the village church. "He put it in his shirt pocket. Later he was hit by a bullet that remained stuck in the bible. That saved his life." In an interview with a Dutch documentary filmmaker, the girl's father confirmed her story: "I survived that shot in my chest because of that little bible," as he showed her the bible with the bullet hole. ${ }^{69}$ While miniature bibles and Qur'ans nestled close to bodies, other personalized religious tokens were more public, some even growing in size, like the bling crosses that young Protestant men, often the same persons who helped put into place the monumental Christian murals, took to wearing around their necks. Besides T-shirts and crosses, the colored head ties worn by Christians and Muslims, and the amulets and religious artifacts they carried into battle, jihadist propaganda DVDs display a fantastic array of Islamic calligraphy inscribed on headbands and across shirts in a revival of an older wartime practice. $^{70}$

Things also stood at the center of delicate and aggressive realignments in the relations between coreligionists. As the war dragged on, I heard how some local Muslim leaders began to cautiously complain about the exacting demands of the Laskar Jihad, whose arrival in the city early on in the war they had initially welcomed with open arms. The complaints were articulated across a widening rift in which Muslim Ambonese detailed the jihadis' inherent difference from themselves in primarily material terms-singling out their untrimmed beards, cropped trousers, and robes and the long, black attire of their women. Other border skirmishes include two iconoclastic events-one among coreligionists, the other pitting Muslim against Christian. The first involved Pak Nus Tamaela, one of the indigenous Christ painters, who at the behest of several Pentecostal ministers destroyed, in what his son called a "crisis of faith," the cement statues and paintings of ancestral Malukan war leaders that he had produced over the years. ${ }^{71}$ A second event, related by Ambon's former bishop Monseigneur Andreas Sol, involved a saint's portrait whose painted eyes somewhat unsettlingly pursued the viewer. When Muslims occupied the general area in which the church with the saint's portrait was located, it so unnerved them that they rapidly provided the saint with a pair of painted dark glasses. There is much to say about these episodes, in particular the potential for animacy that haunts them both and that was implicitly acknowledged in the first 
instance in the destruction of the headhunter effigies and, in the second, the defacement of the saint's portrait, but I discuss them elsewhere. ${ }^{72}$

Through the untoward behavior of things and the ways in which both objects in motion and those serving as community signposts delineated, undermined, and repeatedly reinscribed this Malukan field of urban religion, religion's salience as an important legacy of the long Suharto era also comes to the fore. Center stage in such a field-indeed, the very starting point of this treacherous affair-is not simply matter out of place but a multitude of shape-shifting, death-dealing things whose power to harm is only revealed after the fact, once it is too late, through their affective and material consequences in the world. Much like acts of terrorism, the effects of such things make tangible and visible what hitherto had been present, yet unseen. ${ }^{73}$ It is telling, in this regard, that the voice of Salma, increasingly anguished, reportedly cried out in church for the small stone of which she had been bereft and that, fetishistically, held sway over her, "Stone, stone, stone, where are you?" The power of things and the deceptive nature of appearance in Ambon's wartime was further disclosed not only through alterations in the shape of objects, including the impact of dramatically varying scale, but in the discourse surrounding the fugitive identities of persons in the conflict's thick, murky reality.

\section{Symptomatology: Treacherous Persons}

Haunting by an Other can also gesture elsewhere-not only to displacement, annihilation, and the forging of hard-edged, simplified identities but to the inability to foreclose the other. Haunting is a disturbed acknowledgment, however tenuous and oblique, of an ethical claim of an Other upon the self. This means foregrounding in the scene of possession the sense of being overtaken by force, or summoned by a call or demand that cannot be refusedan agency, in other words, that has everything to do with haunting. This, I propose, is what Ambon's scene of possession also has to offer. I am encouraged to take this route rather than one that leads only to entrenchment and violence by cues from Ambonese Christians themselves. Many, to be sure, insist that their own faces are illuminated as opposed to what they describe as the dark illegibility of the Muslim, or what is also spoken of as the latter's inherent lack of aura. Allowing the illuminated Christian face to triumphwhether in the miracle of the Lord's appearance to a Muslim convert confirming her "possession" by the Christian spirit or in everyday invidious comparisons from which Christians, in their own view, emerge shiningchallenges the Christian eclipse by potent Muslim agency in the GPM minister's account. 
Famously, Emmanuel Lévinas singles out the face of the Other as the site of a particular ethical injunction, as bearing within it an infinite demand. ${ }^{74}$ The sign of a radical, inassimilable alterity, the face signals an interruption. It conveys "a demand that I become dispossessed in a relationality that always puts the other first." 75 It also assumes that this other is inassimilable, something that interrupts my own continuity, thereby making impossible an "autonomous" self at some distance from an "autonomous" other. ${ }^{76}$ This ontology of the self constituted via a prior eruption at the core of the self entails a critique of the autonomous subject, one that also undermines a view of cultures or, for that matter, religions as autonomous domains among which dialogue should be established. ${ }^{77}$ It evokes instead a much more complicated, entangled sense of plurality and cohabitation.

This disavowal of the possibility to constitute fixed and stable identitarian positions is characteristic of work in political theory and political philosophy that, while drawing on Carl Schmitt's political theology with its emphasis on the friend/enemy distinction, attempts to move beyond its totalizing implications. Such work highlights the possibilities of semantic slippage and reversal in Schmittian perspectives-underscoring how the enemy can be a friend, the friend is sometimes an enemy, how the border between them is fragile, porous, and contestable. ${ }^{78}$ This slippage can open the way to a political theology of the neighbor, a third position alongside that of friend and enemy, an exception to the exception of sovereignty to which I will return. ${ }^{79}$ But it can also describe a scene of terror like that of Ambon during the war.

On the ground in Ambon, things were often no clearer, facilitating their own hazardous slippages. If Christian Ambonese tended to assert a clear difference between their own faces and those of Muslims, many also maintained that this difference is immediately apparent. At least in a pronounced sense, this seems a recent development in the relations between Christians and Muslims in Ambon. A journalist friend who called the conflict a monster described how, before it, the city's Christians and Muslims would often be invoked in a single breath as "Salam-Serani" or a conjoined "Muslim-Christian" pair. As a child, he recalled, he could tell the difference between Muslim and Christian, but only during the war did such difference become something truly to be seen, as it also spawned a slew of new terms like red and white, Acang and Obet, or Islam and Kristen that marked the rift of enmity that had become consolidated between former neighbors. ${ }^{80}$ Running through a list of distinctions of dress, religious symbols, and dialectical variation, my journalist friend confided, lowering his voice, that "our faces are more illuminated." 81 Similarly, and with equal circumspection, one of Ambon's young painters explained, while speculating that God may have bestowed such signs to distinguish Christians from 
Muslims, that the difference between them came down to illumination: Christians bathe in divine light, while Muslims lack aura.

Remarkably, this certainty glosses -if barely-a radical uncertainty. While prepared especially during the Islamicization of the late Suharto years, uncertainty became aggravated during the conflict. It pertains in particular to the identities of friend and enemy, to the positioning, more broadly, of Muslim and Christian with respect to each other, and, most poignantly for Protestants, to the status and location-indeed, even physical presence and futurity-of Christians in Ambon and in Indonesia generally today. Excerpts from an interview with a civil servant from the city's provincial forestry department, who I will call Hengky, demonstrate how the assertion of a radical, discernible difference between Muslim and Christian dissolves, again and again, into uncertainty. Quite canonically, the topic was spies who had infiltrated his majority-Christian neighborhood during the war and had been discovered and brutally killed. Such talk is an instance of the larger discourse distinguished by what I call an aesthetics of depth, since it revolves around the disguises, dissimulations, and deceptive identities held to be prevalent during the war and the countermoves these provoked to penetrate the treacherous appearances of persons and things, the dense, layered reality described in Chapter 1. What this discourse makes clear is that while difference may be something one can see, what one sees cannot necessarily be trusted. This fine line can make all the difference-indeed, even between life and death. Of particular concern were fake national armed forces soldiers who turned out, the man claimed, to be spies, an identity that recalls the army uniform in a stringer's clip that the camera repeatedly circles over as if to summon forth another reality beneath its khaki surface (see Chapter 1). When I asked how he knew they were Muslims, he explained:

Because you know. There is a difference between Muslims and Christians-they are different. You can see it ... We have been associating with them for a long time so we can tell, "Oh, that's a Muslim." It's like that for Christians down in the city, they know, too, "Oh, that's a Christian." You can tell right away because it has been a long time that we have been living together.

But once in a while, there's a Christian who looks to us like a Muslim. Like our people from Toraja. Torajans have traits like Buginese, right? [Designating members of the Muslim diaspora from South Sulawesi, many of whom have been present in Maluku for centuries, including in Ambon.] Just like Buginese. "Wah, that's a Muslim!" If you ask him, 
[he'll say] "No, I'm a Christian," but he would not be believed. And if at some time, there is an armed crowd, a Christian crowd, and he panics because there's a really large mob-with machetes, all kinds of weapons-and they want to kill him, he panics! But if someone comes along and asks him really calmly, and there is someone who knows him who can say, "Oh yes, it's true! He's from Batugajah, he's a Christian," then it's safe, just like that. But if no one knows him, that's it, it's over right then and there. ${ }^{82}$

While indigenous Christian and Muslim Ambonese would recognize each other spontaneously, he claimed, these other cases had to do with "people from elsewhere, Christians from outside, for instance, like the ones who look like Buginese that I mentioned before. That was sadistic-because we thought they were Muslim."

It took little, apparently, for confusion between Christians and Muslims to set in, for the adamant assertion of certainty to unravel, even if here such confusion is projected onto Christians from outside Maluku. Besides the occasional "Judas" or Christian who, for payment, would set fire to Christian property, another topic that came up in the conversation brought such uncertainty even closer to home. During the war, among the array of signals they used to communicate with each other, Christians deployed secret passwords as a means of recognizing each other and sorting friend from foe. Although Hengky mentioned it was commonly after nightfall when such codes were used-implying that in daylight one would know a fellow Christian by their face-this example suggests that spotting a Christian or, for that matter, a Muslim is less straightforward than many claim. Within the exceptions raised to the immediate recognition of Christian versus Muslim, the password counts as yet another sign of uncertainty that surfaced in our conversation to undermine the certainty with which it began. Even as this uncertainty was displaced into the darkness of night or onto non-Ambonese, it hinted at the enormous fears and risks of slippage and reversal-how the enemy may be a friend, the friend sometimes an enemy. More urgently, the border between them-patrolled by the anticipatory practices of an aesthetics of depth, by passwords to secure identity, and by the other tactics and symptoms of war-is fragile, porous, and dangerous. Like that of the possessed Javanese convert, this example exemplifies the extent to which an aesthetics of depth haunted war's terrain as surface manifestations became suspect and treachery lurked behind the most banal appearances. It also confirms, as the epithet to this book asserts, how the true mystery of the world is not the invisible but the visible. 


\section{Neighbors and Neighborhoods}

The moving stone that set off Ambon's possession captures the necessary dynamism at the heart of cohabitation, a relationality that, admittedly, only in the best of possible worlds amounts to a dispossession that always puts the other first. This is clearly not the situation in Ambon, nor, of course, has it ever been, but we may catch a glimmer of this possibility - admittedly, oblique and tenuous-in the Javanese convert's dramatic possession that frames this chapter: "The principle of conversion, of one person insinuating his or her mode of interpretation in the mind of another, informs all dialogue." ${ }^{83}$ Street names, family names, and conventional ways of designating neighborhoods and areas in Ambon intimate a story of such mutual "insinuation" in the astonishing admixture and long-standing side-by-side living that these document. Family names like Gasperz, de Lima, Bahaweres, van Blauw, van Heling, van Houten, de Fretes, de Queljoe, Basalama, Alkatiri, Alhabsi, Veerman, Camerling, Kastanya, Alfons, Rugebrek, de Jong, van Room, van Broudhorst, Van Harleem, Muskita, da Costa, Engels, van Hof, Bremer, Parera, Payer, Seslovski, Olchevski, de Sousa, Noya, van Delsen, van Bergen, Souisa, de Keizer, Roehoebrek, Hamdan, Waas, Mendoza, Alhamid, Alatas, Alhadar, Bachmid, Atamimi, and no doubt others attest to the long history of trade and colonialism-including that of the Dutch East India Company, designated in the Netherlands as the world's first multinational company-and to the presence of Portuguese, Arabs, Spaniards, English, and others, many of whom preceded the Dutch in Maluku. Add to this list the names of Indonesians from elsewhere, today and in the past, Javanese, Buginese, and Makassarese, Malukans from Ambon-Lease and from the islands to the north and south, not to mention the many slaves and the colonial and postcolonial government employees, naturalists, and adventurers who visited the city through the years. Street and alley names show how this diversity inscribed itself in Ambon's formal and informal infrastructure: a casual survey of gang, or urban alleys, yielding Gang Violeta, Gang Yosef Kam, and Gang da Silva; jalan, or street, offering Jalan Valentijn, Jalan Franciskus Xaverius, and Jalan Anthoni Reebok; with the areas of Tantui (Tan Hui), Menerlimfrom the Dutch "Meneer Lim" for "Mr. Lim" or, as my journalist friend Novi Pinontoan corrected, "actually Tuan Lim"-and Hongko Liong evidencing the important Chinese presence; and, finally, OSM, an acronym for the Dutch Opleiding School Maritiem, standing in for the neighborhood where the colony's Maritime Training School once stood. ${ }^{84}$ Today, all of these historic names blend with those bestowed under the Indonesian Republic, commemorating its many heroes and replicated across the country in the nomenclature of its cities and towns. In addition to these examples, there are all those groups and 
persons who, in myriad ways, also left their marks by passing through or settling in the city, but whose names do not appear in its official topography. Although the old names endure, at least in memory, this palimpsestic urban space was written over and partially erased as the war's violence zoned the city into red and white neighborhoods - the territories, respectively, of Acang and Obetidentified several Malukan Gaza Strips to publicize this difference, and as some streets were renamed in Muslim areas to reflect the successes of jihad, like Martyr Street.

Under what conditions does ideological clarity become urgent, necessary, or unavoidable? When is it more compelling to stake out hard-edged, simplified positions-socially, spatially, and representationally-than to leave things flexible and fuzzy at the edges? This chapter documents the story of religion under the sign of crisis, a story of a dramatically shifting terrain in which the Christian Javanese refugee possessed by Muslim spirits is not alone in her fraught, layered subjectivity but surfaces within a cluster of similarly complicated if less problematically crossed figures. Recall from the previous chapter Minister Mohammed, who baptized the self-described former worshipper of statues and Chinese Indonesian convert to militant Christianity, or the avid fan of Seram's allegedly bellicose ancient headhunting culture and father of ministers from competing Christianities, or the painter of Ambon's apocalypse who embraced Pentecostalism following his narrow escape from death. Far from forgettable instances of religion on the fringe, these persons and others like them occupied the very center of an urban environment in the grips of diabolical crisis, one that exposed its fractures, imbalances, and points of tension-with all the distress, upheaval, and terror that accompanied that. Beyond simple exposure, the fault lines these people exemplify point to deep seismic shifts in Ambon's social, religious, political, and, crucially, aesthetic terrain, contributing over time to transformations in the distribution of the sensible in the city and beyond.

Emerging side by side in Ambon's postwar environment, its scenes of possession and proliferating Jesus faces seem to pull in opposite directions. If the possessions intimate the possibility of an ethical injunction, of the Christian inability to cancel or close out the Muslim, the gigantic Jesus pictures appear to accomplish just that. Monumentalizing the Christian face on the ruins of the recent war appears to proclaim at one and the same time the facelessness of the Muslim. In light of the uncertainty that undermines Christian assertions of a clear-cut distinction between their illuminated faces and the auraless ones of Muslims, the Jesus pictures seem to protest too much. This protest both realizes itself and dissipates in the drive to monumentalize Christian community icons, in the repaintings and refreshings to which the paintings were periodically subject, and in the reiteration of Christ's portrait again and again. 
Much as their gigantic scale, the refreshings have the effect of enhancing the pictures-with brighter colors and clearer outlines, they stand out better in public space. In the immediate postwar, it was as if Ambon's Christians could not do enough to proclaim the pictures' presence. All of these efforts imply that a single picture or even multiples did not suffice to carry out the work for which they were intended. Precisely the pictures' huge, multiplying status hints that even infinite reproductions might be unable to achieve the demands made of them, while also highlighting the dubious grounds on which the identitarian claims they portray were constructed. The pictures disclose the inability-no matter how many are put in place or how big they might be-to foreclose the Muslims who live with and alongside the Christians, making Ambon the fascinating, complicated, multireligious, and multiethnic urban reality that it is. From this perspective, Christ's painted face, much like possession, if more obliquely, is haunted-by the Muslim who hedges and delimits the Christian like some energetic dark shadow.

Barring some exceptions, like Silale with its many migrants, most of Ambon's neighborhoods were not only traditionally segregated on the basis of religion and ethnicity, following colonial policy, but also tightly knit. Certainly, this was and continues to be the case for those neighborhoods that are traditional GPM strongholds. This is also where women come into the picture. Recall that among the five members of the GPM prayer group where the possessions took place, four were women. In Ambon, as in many parts of the world, women guarantee the everyday fabric of the religious lifeworld-as the crucial nodes of Christian neighborhood and congregational sector networks and by ensuring the weekly cycle of domestic and neighborhood prayers, organizing life cycle events, producing the food served on these and other occasions, and running the numerous church drives and collections. Within the congregation they occupy important positions; indeed, Ambon boasts many women ministers. As scholars note, for Ambon and other parts of Indonesia that have witnessed religious violence, government institutions and offices, local political economy, and social life tend generally to be organized along religious lines. Religion in such places is not limited to the church but defines the very structure of society. ${ }^{85}$ That the large majority of those possessed in the minister's account were women therefore points to something else-namely, the anxiety among Protestants that the very fabric of their lifeworld was under siege, one held and woven together in significant, religiously defined ways by women. If the possessions struck at the intimate core of the GPM's wartime congregational life-the tiny prayer groups set up during the conflict-so, too, does the predominance of women protagonists in this event underscore how invasive the city's diabolical crisis was. In singling out women, the demonic possession 
attacked the gendered lineaments that sustain the network of sector and subsector organization binding neighbors and neighborhoods, bringing them together regularly in a range of religiously defined constellations, all mobilized by and dependent on women. Besides the daily flow of gossip, mutual assistance, and common need or interest that characterize neighborhoods almost everywhere, the weekly cycles of prayer, along with the socializing and food sharing that accompany them, tightly structure the space and time of Ambon's Christian neighborhoods along gender- and age-based lines-with, for instance, an all-male prayer group scheduled on Tuesday evenings, that of women on Wednesdays, adolescents on yet another day, and so on-that crosscut wider family and extended kin ties. More generally, the New Order and post-New Order state have relied on women's labor to produce key political and economic orders in the name of neighborliness through national organizations like the one for female civil servants and civil servants' wives. ${ }^{86}$ From the time of the Japanese occupation of Indonesia during World War II, neighborhoods have also been key building blocks of state control and monitoring of the population, a form of governmentality that was ideologically reinforced by terms that codified the alleged traditional values of neighborly cooperation and mutual assistance. $^{87}$

If the production of a neighborhood, under any conditions, can itself be understood as the exercise of power over some form of recalcitrant environment, then the Christian neighborhood, with its tight skein of crosscutting relations and weekly and annual Christian rhythms, exemplifies this kind of production. ${ }^{88}$ This explains why such neighborhoods so readily became the rallying point for collective, religiously defined action in wartime. But other stories also emerged during the conflict, notably from religiously mixed neighborhoodsstories of people protecting and harboring their neighbors from "the other side" against attacks from their coreligionists, often at risk to their own lives. Nor were all the displacements that resulted in the religious purification of the city's neighborhoods solely motivated by aggression. A moving collection of accounts of nonviolent resistance at the grassroots level from different parts of Indonesia, including Maluku, where violence occurred during the unraveling of Suharto's regime offers countless examples of people standing up to defend their neighbors, combatting prejudice and rumors. ${ }^{89}$

At times, this meant escorting them out of their neighborhood to a place of greater safety where they could live alongside people of their own religion. Other stories celebrate soccer's diplomacy or small, courageous gestures, like making token purchases at the Christian kiosk across the road from a Muslim neighborhood, a public performance meant to be seen by others. When neighbors did turn on each other, they often, apparently, relied on others, coreligionists 
from elsewhere, to do the dirty work vis-à-vis their immediate neighbors. Apart from neighbors, schoolmates and officemates of different religions would meet each other, when possible, at the barricades set up in the city center, at military checkpoints, or on payday in the case of civil servants. Cellphone text messaging offered another means of connection. To be sure, such contact was limited, often impossible, and came with considerable risk, especially from coreligionists. In the public service announcement featuring the Muslim Acang and the Christian Obet, this kind of contact is sentimentalized in the boys' prearranged, clandestine encounter (see Chapter 1). The fate of this PSA, however, which provided the conflict's most popular names of enmity, suggests how dangerous and contested such contact must have been.

Until now, I have written of literal neighbors, of peoples who have lived side by side for a long time, have shared with or shunned each other, have exchanged and communicated, positively and negatively, in myriad ways and in shifting historical and political circumstances. To restrict this account, however, to a pair of two, the encounter of the neighbor and the self, is to forego the possibility of conceiving of the third or the mediation and symbolic representation on which any politics is based..$^{90}$ An ethics of two inevitably involves a choiceone chooses this neighbor over that-and thus ends up dividing the world into friends and enemies. By contrast, politics moves beyond the face-to-face relation to open out onto an infinite series of potential encounters, "without limit and without totalization, a field without the stability of the margins." Seen in this light, the neighbor would coincide with the stranger-not just the faceless one but the faceless many otherwise left in the shadow in the privileging of the one. ${ }^{92}$

With this in mind, it is worth looking again at Ambon's Christian billboards and especially how they are positioned in urban space. With few exceptions, the billboards and murals face outward, turning away from what, for all practical purposes, became gated communities to confront whoever passes them by. Commonly, they stand at Christian neighborhood entrances on curbs and sidewalks at the edge of public streets and on land usually owned by the city. Yet, if these pictures gate and brand the community, they also seem to extend an invitation outward-to others and to strangers to look back. If this appears too outrageous a claim, think then of the advertisements whose location the Christian pictures often usurp or recall the gigantic suffering Jesus faces that dot the highway and greet the visitor on her way from Pattimura Airport into Ambon-whether she is a fellow Malukan or Indonesian from elsewhere, a government or business envoy from Jakarta, a national or international NGO activist or humanitarian aid worker, a returning migrant, a vacationing Dutch Malukan, a journalist, a tourist, a stranger. 
A Muslim woman who was active in a local NGO that worked closely in some of the city's refugee camps with a partner Christian organization identified the addressee of the Christian pictures as the stranger or persons from elsewhere who, predominantly as part of the transnational humanitarian aid industry, ${ }^{93}$ flocked to Ambon during the war and the years immediately thereafter. In her view, the pictures were not aimed at enemies or ill-intended strangers but served as helpful signposts assisting those unfamiliar with the city to navigate its treacherous georeligious patchwork of segregated space, nogo areas, and friendly versus hostile terrain. ${ }^{94}$ The broader conditions of the postwar city-especially its displaced and refugee populations, returning migrants, densely packed neighborhoods, and urban crowds, not to mention its recent history of a city "possessed," along with the sheer pragmatics of living with religious and other pluralities-are relevant to any thinking about neighbors and neighborhoods. While neither the possibility of violence nor the desire for the other's elimination have been exorcised from the postwar city, I close this chapter by suggesting how the scene of Ambon's possession hints at something else-namely, the possibility of a resignification of the friend/enemy contrast, which would open out onto the social bond that moves one away from intractability and the hard terms of stark oppositions. Considering spirit possession and the city's Christian pictures in the same frame positions these two sites in the postwar city that-however strangely and obliquely-open the possibility of a distinct political theology of the neighbor. Taken together, they intimate a way where haunting signals cohabitation, the possibility of a generosity toward one's others and toward strangers. 


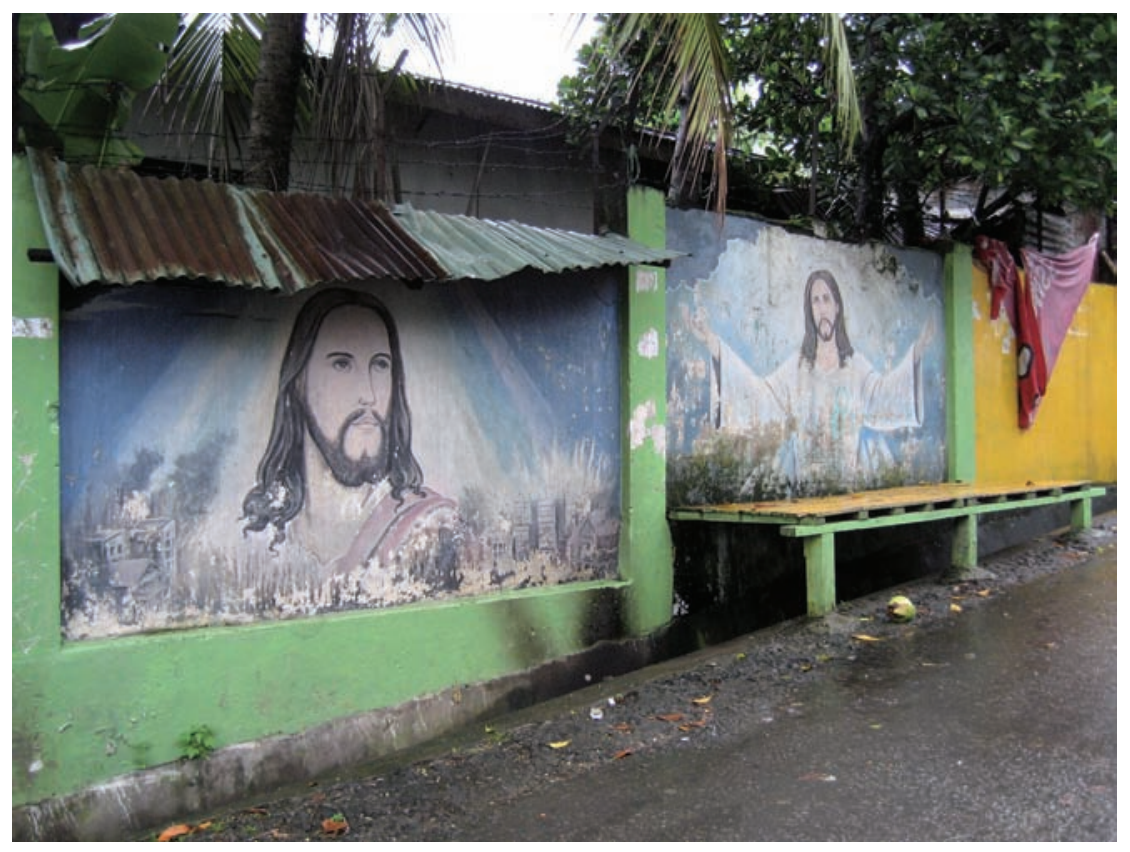

Figure 34. Alleyway with faded murals of Christ overlooking the city of Ambon exploding with violence, Ambon, 2005. Photos by the author.

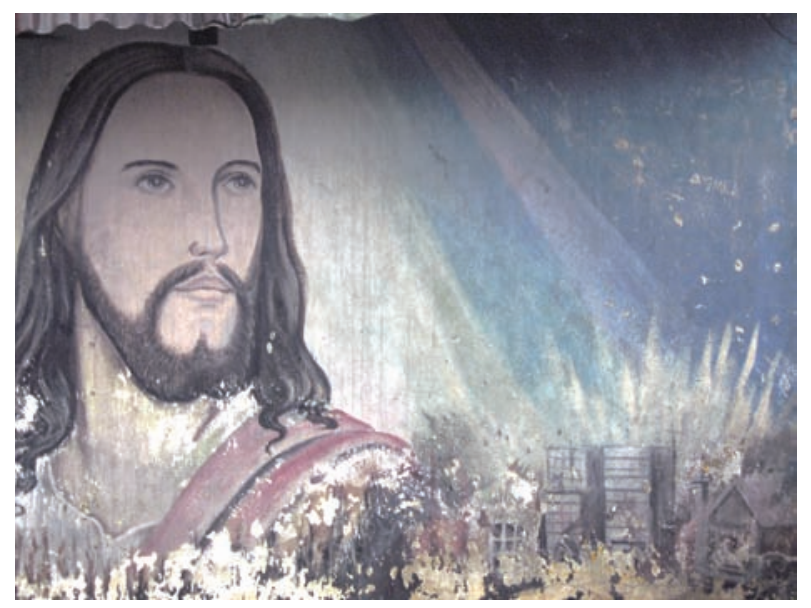

